\title{
Assessment of water quality in the rivers of Abkhazia, based on zooplankton
}

\author{
Olga Yu. Derevenskaya', Gulina M. Gilmullina1', Nafisa M. Mingazova1, \\ Roman S. Dbar ${ }^{2}$
}

\begin{abstract}
${ }^{1}$ Department of Environmental Engineering and Water Resources Managment, Institute of Management, Economics and Finance, Kazan Federal University, 18 Kremlyovskaya street Kazan 420008, Russian

Federation, Russia, ${ }^{2}$ Institute of Ecology of Abkhazia, Republic of Abkhazia, Sukhumi
\end{abstract}

\begin{abstract}
Objective: A number of water objects of Abkhazia (the Western Caucasus) have been studied. Physicochemical indicators of water and characteristics of zooplankton community were investigated. Water bodies of Abkhazia are specified by high water quality, due to glacier-derived nourishment of rivers. In the mouth areas, the quality of water deteriorates, sometimes significantly, due to the pollution by sewage. However, most of the studied water bodies have high quality of water. The exceedance of maximum permissible concentration of biogenic elements was not revealed in rivers. In waterfalls water is ultra-fresh. In rivers, water is fresh with low hardness. Materials and Methods: A total of 17 zooplankton taxa were identified in the studied water bodies. The dominant species in various water objects were the following: Thermocyclops crassus, Pleuroxus aduncus, Pleuroxus trigonellus, Alona rectangula, Penilia avirostris, Macrothrix laticornis, and Eucyclops serrulatus. Zooplankton communities are characterized by low species richness. It is due to the high flow rate of mountain rivers, and their low temperature that creates unfavorable conditions for the development of zooplankton. Results and Discussion: The abundance of zooplankton varied from 5 specimens $/ \mathrm{m}^{3}$ (the Mokva River) to 570 specimens $/ \mathrm{m}^{3}$ (the Edyrtaa River). The biomass of zooplankton varied from $0.127 \mathrm{mg} / \mathrm{m}^{3}$ (the Mokva River) to $5.1 \mathrm{mg} / \mathrm{m}^{3}$ (the Akuna Channel). Quantitative indicators of zooplankton are low. Conclusions: According to the value of saprobity index, water in the Dzyguta, Edyrtaarivers, the channel from the Gali reservoir refers to $\beta$-mesosaprobic zone, and water in the Kudry Khuchi and Smyrakha rivers - to oligosaprobic zone.
\end{abstract}

Key words: Abkhazia, bioindication, river, water quality, zooplankton

\section{INTRODUCTION}

A bkhazia is located on the northeastern coast of the Black Sea, bordering with Russia and Georgia. The area of the territory is small, the distance from the northwestern border to the southeast is $170 \mathrm{~km}$, and from the southern to the northern $-66 \mathrm{~km}$. The total area of Abkhazia is 8665 thousand square kilometers.

The territory of Abkhazia covers 2 climatic zones - subtropical and moderate. Formation of climate depends on the geographical latitude and temperature. The climate in the mountainous and lowland parts is different. The proximity of territory location to the sea determines the temperature in winter period. ${ }^{[1]}$ The annual amount of precipitation on the coast of the country is $1500 \mathrm{~mm}$, in the mountains $-2500 \mathrm{~mm}$. Due to the proximity of sea, the climate is rather humid. Late autumn and winter are rainy. ${ }^{[2]}$
Abkhazia is well provided with water resources. It occupies leading position for water supply. About 1.7 million cubic meters of water are accounted for by a square kilometer of the territory. This is mainly the catchment area of mountain rivers. Abkhazia is rich in rivers. The largest rivers flow in the valleys, which are located at the foot of the southern slope of the Greater Caucasus. There are $>150$ valuable mineral springs in the republic. It is also rich in lakes. Their number exceeds 180. As for their origin, most of them are glacial lakes. ${ }^{[3]}$ The water from some of them is used for drinking purposes.

\section{Address for correspondence:}

Olga Yu. Derevenskaya, Institute of Management, Economics and Finance, Kazan Federal University, 18 Kremlyovskaya Street Kazan - 420 008, Russian Federation, Russian. E-mail: oderevenskaya@mail.ru

Received: $22-11-2018$

Revised: 09-12-2018

Accepted: 15-12-2018 
To date, the water bodies of Abkhazia are understudied. There is limited information about the zooplankton of this region. ${ }^{[4]}$ At the same time, zooplankton is an important component of aquatic ecosystems, which has indicative properties. Indicators of the structure of zooplankton community, as well as the indices, based on the indicative properties of plankton organisms, along with physicochemical characteristics of water, allow to assess water quality in water bodies and their trophic status. ${ }^{[5-7]}$

The aim of the work is to assess the water quality of the water bodies in Abkhazia, based on zooplankton. This involves the solving of such tasks as the determination of species composition, defining the abundance and biomass of zooplankton, calculation of biotic indices and estimation of water quality.

\section{MATERIALS AND METHODS}

The water bodies of the Republic of Abkhazia were studied on July 10-20, 2015, and August 20-25, 2017, during the expeditions of the Department of Environmental management and water use of the Kazan Federal University. The following water bodies were investigated: The Dzyguta (August 22, 2017), Kudry-Khuchi (August 25, 2017), Smyrakha (23, 2017), Bzyb (August 23, 2017), Barnaut (August 24, 2017), Edyrtaa (August 22, 2017), and Mokva (July 12, 2015) rivers; the Velikan (August 24, 2017), Akarmarsky (August 24, 2017), and Shakuransky (July 14, 2017) waterfalls; the creek Uaz-abaa (July 13, 2015) and the creek in the Monashskoe gorge (August 23, 2017); the Akuna (August 25, 2017), Magistralny (August 23, 2017) channels, and the channel from the Gali reservoir (July 16, 2015).

The samples of zooplankton were taken using the Apstein net. From 50 L to $200 \mathrm{~L}$ of water were strained through the net. Samples were fixed with $40 \%$ formalin.

Laboratory investigation included the determination of species composition, counting of numbers and calculation of biomass. The calculation of the abundance and biomass of zooplankton were performed in accordance with generally accepted hydrobiological methods. ${ }^{[8]}$

The degree of zooplankton diversity was estimated using the Shannon index $(\mathrm{N})$ (by number). ${ }^{[9]}$ The $\mathrm{N}$ of saprobity (S) was calculated using the method of Pantle-Buck in the modification of Sladeček. ${ }^{[10]}$

Samples of water were taken at the same time with the sampling of zooplankton. Water was sampled into plastic bottles of $1.5 \mathrm{~L}$. Hydrochemical analysis of water samples was carried out at the Abkhaz State Center for Environmental Monitoring, commissioned by the Institute of Ecology of the Academy of Sciences of Abkhazia. We express our deep gratitude for the results.

\section{RESULTS AND DISCUSSION}

Physical and chemical investigations of water from rivers showed that in terms of mineralization it refers to the fresh, hydrocarbonate-calcium type, with a neutral reaction of the medium (the Dzyguta River), or weakly alkaline (the KudryKhuchi, Bzyb, Barnaut, and Edyrtaa rivers) [Table 1]. In terms of the total hardness, the water in the Dzyguta River refers to the soft; in the Kudry-Khuchi, Bzyb, Barnaut, and Edyrtaa rivers - to moderately hard.

The highest content of ammonium ions (4.12 mg/l) was noted in the Dzyguta River. It exceeds the permissible standards by 2.2 times.

Water in the Mokva River was characterized by high transparency $0.75-1.15 \mathrm{~m}$, lack of color and smell, with "low" mineralization. Calcium prevailed among the cations, hydrocarbonates-among the anions. The value of total hardness characterizes water as "soft." Concentrations of total iron and silicon were within normal limits. The concentrations of ammonium, nitrates, and phosphates did

\begin{tabular}{|c|c|c|c|c|c|}
\hline Indicators & Barnaut & Bzyb & Dzyguta & Kudry-Khuchi & Edyrtaa \\
\hline $\mathrm{NH}_{4}^{+}, \mathrm{mg} / \mathrm{l}$ & $<0.01$ & 0.05 & 4.12 & 0.1 & 0.05 \\
\hline $\mathrm{Na}^{+}+\mathrm{K}^{+}, \mathrm{mg} / \mathrm{l}$ & 17.52 & 84.96 & 21.6 & 18.24 & 36.72 \\
\hline Total hardness, mg-ekv./l & 3.44 & 3.54 & 2.88 & 3.78 & 5.58 \\
\hline $\mathrm{Ca}^{2+}, \mathrm{mg} / \mathrm{l}$ & 57.11 & 30.06 & 46.09 & 58.51 & 80.36 \\
\hline $\mathrm{Mg}^{2+}, \mathrm{mg} / \mathrm{l}$ & 7.17 & 24.79 & 7.05 & 10.45 & 19.08 \\
\hline $\mathrm{Fe}^{2+}+\mathrm{Fe}^{3+}, \mathrm{mg} / \mathrm{l}$ & 0.03 & 0.01 & 0.05 & 0.02 & 0.03 \\
\hline $\mathrm{Cl}-, \mathrm{mg} / \mathrm{l}$ & 7.63 & 102.45 & 8.82 & 5.6 & 43.76 \\
\hline $\mathrm{SO}_{4}{ }^{2-}, \mathrm{mg} / \mathrm{l}$ & 0 & 18 & 25 & 7 & 90 \\
\hline $\mathrm{HCO}_{3}^{-}, \mathrm{mg} / \mathrm{l}$ & 237.97 & 109.83 & 189.15 & 253.22 & 242.85 \\
\hline $\mathrm{NO}_{3}^{-}, \mathrm{mg} / \mathrm{l}$ & 2.66 & 3.1 & 6.64 & 4.87 & 1.77 \\
\hline $\mathrm{PO}_{4}^{3-}, \mathrm{mg} / \mathrm{l}$ & 0.3 & 0.14 & 1.08 & 0.25 & 0.12 \\
\hline
\end{tabular}


not exceed the permissible standards; their content was within the normal range. The value of $\mathrm{BOD}_{5}$, which is $0.1 \mathrm{mg}$ $\mathrm{O}_{2} / 1$, characterizes water as "extremely clean."

In the Velikan and Akarmarsky waterfalls, according to the degree of mineralization, water is ultra-fresh (total mineralization is $50.44 \mathrm{mg} / \mathrm{l}$ ), hydrocarbonate-calcium sodium type, with a weakly acidic reaction of medium $(\mathrm{pH}=6.47)$ (the Velikan waterfall), and neutral reaction of medium $(\mathrm{pH}=6.96)$ (the Akarmarsky waterfall) [Table 2]. In terms of the total hardness, water is very soft. In the creek from the Monashskoe gorge, according to the degree of mineralization, water refers to fresh (total mineralization is $427.58 \mathrm{mg} / \mathrm{l})$, hydrocarbonate-calcium type, with a slightly alkaline reaction of medium $(\mathrm{pH}=8.16)$. According to the value of total hardness, water refers to moderately hard water.

In the Akuna Channel, in terms of mineralization, water varies from ultra-fresh (total mineralization is $97.30 \mathrm{mg} / \mathrm{l}$ ) (at the beginning of the channel) to fresh (total mineralization is $190.98 \mathrm{mg} / \mathrm{l}$ ) (at the end of the channel), hydrocarbonatecalcium type, with neutral reaction of medium $(\mathrm{pH}=6.82)$. According to the value of total hardness, water refers to "very soft."

In the Magistralny Channel, in terms of mineralization, water refers to low mineralized (total mineralization is $1407.97 \mathrm{mg} / \mathrm{l})$, chloride-hydrocarbonate sodium-calciummagnesium type, with a slightly alkaline reaction of medium $(\mathrm{pH}=8.24)$. According to the value of total hardness, water refers to "very hard."

Water in the channel from the Gali reservoir was characterized by low transparency of about $0.1-0.2 \mathrm{~m}$, lack of color and odor, with a high content of dissolved oxygen. Water was characterized by a "low" mineralization. In the water of channel, sodium with potassium dominated among the cations, and hydrocarbonates - among the anions. The value of total hardness characterized the water as "very soft."
Concentrations of total iron and silicon were within normal limits. The content of biogenic elements was within the normal range.

Water in the creek from the Uaz-abaa Cave is saturated with oxygen; the active reaction of the medium is neutral or slightly alkaline. Water is characterized by "average" mineralization, and that conforms to the values of specific electrical conductivity. Calcium was predominant among the cations, hydrocarbonates - among the anions. The value of total hardness characterizes water as "moderately hard." Concentrations of compounds of biogenic elements did not exceed the permissible standards, with the exception of phosphates. The content of phosphates exceeded the permissible standards by 2.4-3.6 times. The values of $\mathrm{BOD}_{5}$ were $2.2-4.3 \mathrm{mg} \mathrm{O} / \mathrm{dm}^{3}$ that characterizes water from "slightly" to "moderately polluted."

17 taxa of planktonic animals, belonging to the following groups of aquatic invertebrates, have been identified as a result of the research of zooplankton: Copepoda (5 species), Cladocera (7 species), and Rotifera (5 species) [Figure 1]. Copepoda referred to 2 families: Cyclopoidae (4 species) and Diaptomidae (1 species). Cladocera belonged to 3 families: Chydoridae (5 species), Sididae (1 species), and Macrothricidae (1 species). Rotifera belonged to 3 families: Brachionidae (3 species), Synchaetidae (1 species), and Euchlanidae (1 species). Most species are widely distributed except for the species Penilia avirostris Dana, 1849, which lives in salt waters and, probably, came from the Black Sea to the mouth part of the river.

The species richness of zooplankton in the water bodies of Abkhazia is low. There were from 1 to 5 species in the samples. The occurrence of zooplankton species in different water bodies was not the same [Table 3]. In some rivers (the Barnaut), in creeks and in water of waterfalls zooplankton was not found.

Table 2: Hydrochemical indicators of water in the studied water bodies of Abkhazia

\begin{tabular}{lcccccc} 
Indicators & $\begin{array}{c}\text { The Velikan } \\
\text { Waterfall }\end{array}$ & $\begin{array}{c}\text { The Akarmarsky } \\
\text { Waterfall }\end{array}$ & $\begin{array}{c}\text { The Akuna } \\
\text { Channel, 1 }\end{array}$ & $\begin{array}{c}\text { The Akuna } \\
\text { Channel, 2 }\end{array}$ & $\begin{array}{c}\text { Creek in the } \\
\text { Monashskoe gorge }\end{array}$ & $\begin{array}{c}\text { The Magistralny } \\
\text { Channel }\end{array}$ \\
\hline $\mathrm{NH}_{4}{ }^{+}, \mathrm{mg} / \mathrm{l}$ & $<0.01$ & $<0.01$ & 0.18 & $<0.01$ & 0.09 & 0.04 \\
$\mathrm{Na}^{+}+\mathrm{K}^{+}, \mathrm{mg} / \mathrm{l}$ & 8.16 & 8.4 & 9.84 & 9.84 & 18.96 & 275.52 \\
Total hardness, mg-ekv/l & 0.31 & 0.3 & 0.83 & 1.99 & 4.58 & 11.27 \\
$\mathrm{Ca}^{2+}, \mathrm{mg} / \mathrm{l}$ & 4 & 4.41 & 12.62 & 32.26 & 79.76 & 144.28 \\
$\mathrm{Mg}^{2+}, \mathrm{mg} / \mathrm{l}$ & 1.34 & 0.97 & 2.43 & 4.62 & 7.29 & 49.46 \\
$\mathrm{Fe}^{2+}+\mathrm{Fe}^{3+}, \mathrm{mg} / \mathrm{l}$ & 0.02 & 0.01 & 0.13 & 0.25 & 0.12 & 0.37 \\
$\mathrm{Cl}^{-}, \mathrm{mg} / \mathrm{l}$ & 3.39 & 4.24 & 4.24 & 3.73 & 7.46 & 593.69 \\
$\mathrm{SO}_{4}{ }^{2-}, \mathrm{mg} / \mathrm{l}$ & 0 & 0 & 7 & 5 & 0 & 80 \\
$\mathrm{HCO}_{3}^{-}, \mathrm{mg} / \mathrm{l}$ & 30.31 & 29.29 & 59.8 & 134.24 & 311.19 & 262.37 \\
$\mathrm{NO}_{3}^{-}, \mathrm{mg} / \mathrm{l}$ & 3.1 & 3.1 & $<1.0$ & $<1.0$ & 2.21 & 2.21 \\
$\mathrm{PO}_{4}{ }^{3-}, \mathrm{mg} / \mathrm{l}$ & 0.11 & 0.02 & 0.06 & 0.03 & 0.5 & 0.03 \\
\hline
\end{tabular}




\begin{tabular}{|c|c|c|c|c|c|c|c|}
\hline Species & 1 & 2 & 3 & 4 & 5 & 6 & 7 \\
\hline Diaptomus sp. Westwood, 1836 & & & & & + & & \\
\hline Acanthocyclops venustus (Norman and Scott, 1906) & + & + & & & & & \\
\hline Eucyclops serrulatus (Fisher, 1851) & & & & & & & + \\
\hline Thermocyclops crassus (Fischer, 1853) & & & & & & + & \\
\hline Mesocyclops leukarti (Claus, 1857) & + & & & & & & + \\
\hline$\sum$ Copepoda & 2 & 1 & 0 & 0 & 1 & 1 & 2 \\
\hline Alona rectangulata Sars, 1861 & & & + & + & & & \\
\hline Chydorus sphaericus (Muller, 1785) & & & & & & & + \\
\hline Disparalona rostrata (Koch, 1841) & & & + & & & & \\
\hline Pleuroxus aduncus (Jurine, 1820) & & & + & + & & & \\
\hline Pleuroxus trigonellus (Müller, 1776) & & & + & & & & \\
\hline Macrothrix laticornis (Jurine, 1820) & & & & & & & + \\
\hline Penilia avirostris Dana, 1849 & & & & & + & & \\
\hline ¿ Cladocera & 0 & 0 & 4 & 2 & 1 & 0 & 2 \\
\hline Platyias quadricornis (Ehrenberg, 1832) & & & & + & & & \\
\hline Euchlanis dilatata (Ehrenberg) & & & & + & + & & \\
\hline Polyarthra vulgaris Carlin, 1943 & + & & & & & & \\
\hline Brachionus diversicornis (Daday) & & & & & & + & \\
\hline Brachionus calyciflorus Pallas, 1766 & & & & & & + & \\
\hline$\sum$ Copepoda & 1 & 0 & 0 & 2 & 1 & 2 & 0 \\
\hline Total & 3 & 1 & 4 & 4 & 3 & 3 & 5 \\
\hline
\end{tabular}

1 - the channel from the Gali reservoir, st. 1; 2 -the channel from the Gali reservoir, st. 2; 3 -the Kudry-Khuchi River; 4 -the Smyrakha River; 5 -the Bzyb River; 6 -the Dzyguta River; 7 -the Edyrtaa River

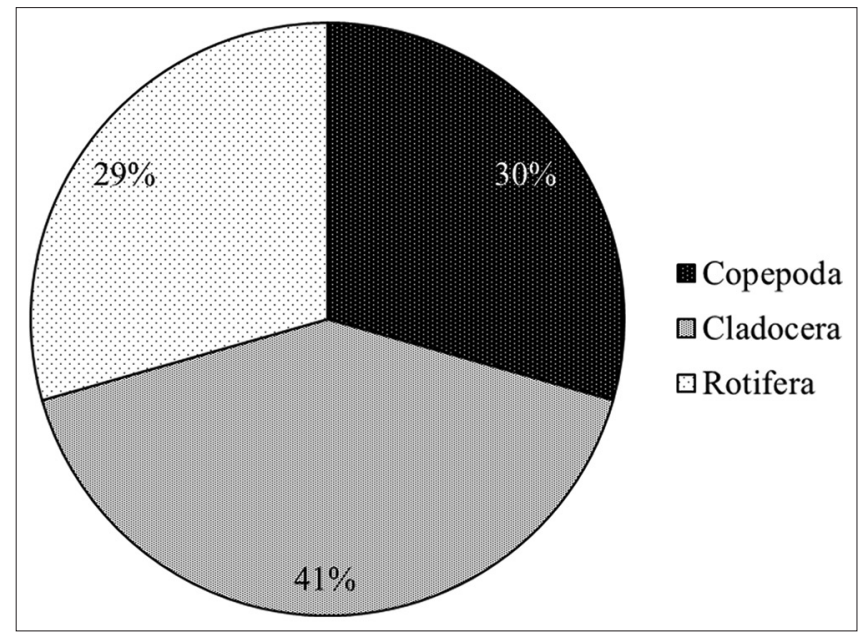

Figure 1: Proportion of species of different taxonomic groups

Studied water objects differ considerably in the composition and quantitative characteristics of zooplankton.

In terms of quantity, Copepoda Thermocyclops crassus dominated in the Dzyguta River, Pleuroxus aduncus, and Pleuroxus trigonellus - in the Kudry-Khuchi River, Alona rectangulata - in the Smyrakha, $P$. avirostris - in the Bzyb, and Macrothrix laticornis - in the Edyrtaa River, M. leukarti in the canal from the Gali reservoir.
In terms of biomass, $T$. crassus is dominant in the Dzyguta River, $P$. aduncus, and $P$. trigonellus - in the Kudry-Khuchi River, P. aduncus - in the Smyrakha River, P. avirostris - in the Bzyb River, Eucyclops serrulatus - in the Edyrtaa River, and Acanthocyclops venustus - in the canal from the Gali reservoir.

In terms of abundance, different groups of zooplankton predominate in all rivers. In the Kudry-Khuchi and Edyrtaa Rivers, Cladocera species were the most numerous. Copepoda species predominate in the Mokva, Smyrakha, Bzyb, and Dzyguta Rivers [Figure 2]. The number of zooplankton varied from 5 specimens $/ \mathrm{m}^{3}$ (the Mokva River) to 570 specimens $/ \mathrm{m}^{3}$ (the Edyrtaa River).

(1 - the Kudry-Khuchi River, 2 - the Smyrakha River, 3 - the Bzyb River, 4 - the Edyrtaa River, 5 - the Mokva River, 6 - the Dzyguta River, 7 - channel from the Gali reservoir st.1, 8 - channel from the Gali reservoir st.2, and 9 - the Akuna Channel).

According to biomass, Copepoda is the predominant group in the Smyrakha, Edyrtaa, Mokva, Dzyguta rivers, as well as in the canals; and Cladocera dominates in the Bzyb, KudryKhuchi rivers [Figure 3]. The biomass of zooplankton varied from $0.127 \mathrm{mg} / \mathrm{m}^{3}$ (the Mokva River) to $5.1 \mathrm{mg} / \mathrm{m}^{3}$ (the Akuna channel). It was very low. 


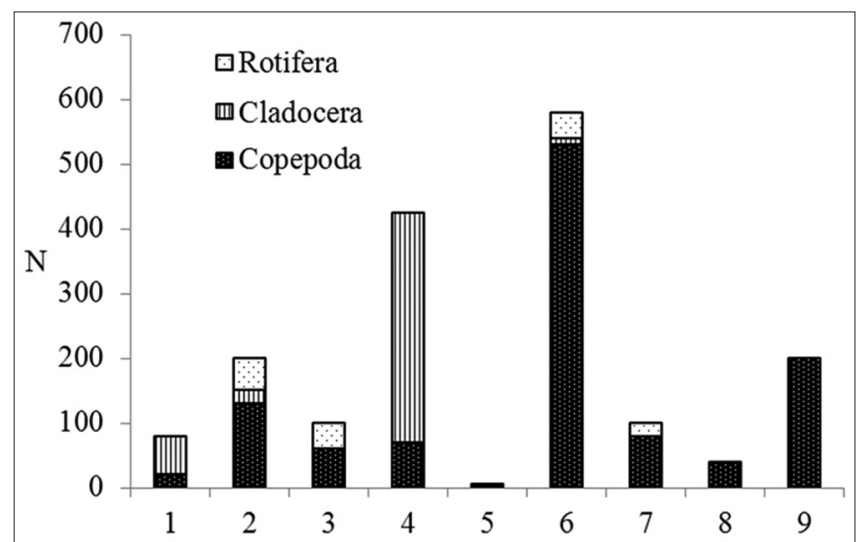

Figure 2: Abundance of zooplankton ( $\mathrm{N}$, specimens $/ \mathrm{m}^{3}$ ) in the water objects of Abkhazia in 2015 and 2017

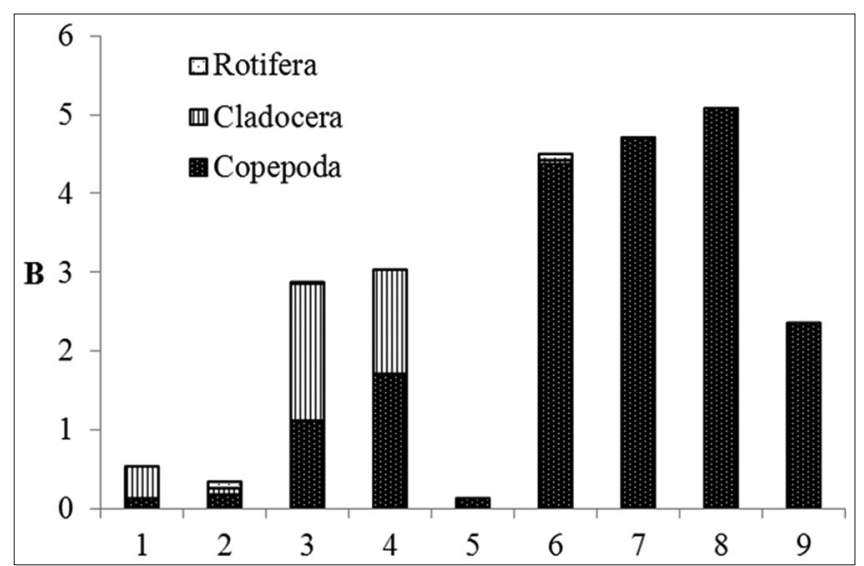

Figure 3: Biomass $\left(\mathrm{B}, \mathrm{g} / \mathrm{m}^{3}\right)$ of zooplankton in the rivers of Abkhazia in 2017

By the value of S N, the Dzyguta and Edyrtaa rivers refer to the $\beta$-mesosaprobic zone; the Kudry-Khuchi and Smyrakha rivers - to the oligosaprobic zone. The rivers, belonging to the oligosaprobic zone, have pure water. B-mesosaprobic zone is characterized by moderately polluted water. The channel from the Gali reservoir refers to the $\beta$-mesosaprobic zone when the water is moderately polluted.

(1 - the Kudry-Khuchi River, 2 - the Smyrakha River, 3 - the Bzyb River, 4 - the Edyrtaa River, 5 - the Mokva River, 6 - the Dzyguta River, 7 - channel from the Gali reservoir st.1, 8 - channel from the Gali reservoir st.2, and 9 - the Akuna Channel)

The $\mathrm{N}$ of species diversity of Shannon was very low. It varied from 1.32 to 1.92 , depending on the water body. This indicates a low species diversity of zooplankton. In most water objects, only single specimens were found.

\section{Summary}

Water in most of the studied water bodies is of high quality. The exceedance of maximum permissible values of the content of biogenic elements was not revealed in rivers. Water in waterfalls is ultra-fresh. Water in rivers is fresh, with low hardness.

17 taxa of planktonic animals, belonging to the following groups of aquatic invertebrates, have been identified in the studied water bodies: Copepoda (5 species), Cladocera (7 species), and Rotifera (5 species).

T. crassus is the dominant species in terms of abundance and biomass in the Dzyguta River. P. aduncus and P. trigonellus are dominant in the Kudry-Khuchi River. In the Smyrakha River, the leader in the abundance is $A$. rectangular, in the biomass - P. aduncus. P. avirostris is dominant in the Bzyb River. In the Edyrtaa River, M. laticornis dominates in the number, and E. serrulatus - in the biomass. The dominant species in biomass in the canal from the Gali reservoir is $A$. venustus, in number - M. leukarti.

In terms of abundance, different groups of zooplankton predominate in all rivers. In the Kudry-Khuchi and Edyrtaa rivers, Cladocera species are the most numerous. Copepoda species predominate in the Mokva, Smyrakha, Bzyb, and Dzyguta rivers. The number of zooplankton varied from 5 specimens $/ \mathrm{m}^{3}$ (the Mokva River) to 570 specimens $/ \mathrm{m}^{3}$ (the Edyrtaa River).

According to biomass, Copepoda is the predominant group in the Smyrakha, Edyrtaa, Mokva, Dzyguta rivers, as well as in the canals; and Cladocera dominates in the Bzyb, KudryKhuchi rivers. The biomass of zooplankton varied from $0.127 \mathrm{mg} / \mathrm{m}^{3}$ (the Mokva River) to $5.1 \mathrm{mg} / \mathrm{m}^{3}$ (the Akuna channel). It was very low.

By the value of S N, the Dzyguta and Edyrtaa rivers refers to the $\beta$-mesosaprobic zone; the Kudry-Khuchi and Smyrakha rivers - to the oligosaprobic zone. The rivers, belonging to the oligosaprobic zone, have pure water. B-mesosaprobic zone is characterized by moderately polluted water. The channel from the Gali reservoir refers to the $\beta$-mesosaprobic zone, when the water is moderately polluted.

\section{CONCLUSIONS}

Abkhazia is rich in water resources. It occupies the leading position for water supply. However, the problem of providing the population with drinking water remains relevant. The use of outdated and war-torn water supply network leads to numerous emergency situations. Sewage is often disposed of without treatment into the sea and estuaries of rivers, and it leads to their contamination.

The research allowed to assess the water quality in a number of water objects of Abkhazia, using physicochemical indicators and characteristics of the zooplankton community. As a result of the conducted investigations, it is found that water in the 
majority of studied water bodies is of high quality, in terms of physicochemical parameters. However, zooplankton is not numerous. Mountain rivers are characterized by high flow rate, low temperature, even in estuarine areas. This creates unfavorable conditions for the development of zooplankton.

\section{ACKNOWLEDGMENTS}

The work is performed according to the Russian Government Program of Competitive Growth of Kazan Federal University.

\section{REFERENCES}

1. Alisov BP. Climatic Zones and Regions of the USSR. Moscow: Geografiz; 1947. p. 211.

2. Drozdov VV. General Ecology: Textbook. St. Petersburg: RSHU; 2011. p. 412.

3. Gulia VO, Orlovskaya TV, Adzinba ZI, Chitanava SM. Physico-geographical characteristics of Abkhazia. Int J Appl Fundam Res 2014;11:35-8.

4. Derevenskaya OY, Mingazova NM. Planktonic rotifers and crustaceans in water bodies of Abkhazia (Western Caucasus). Inland Water Biol 2015;8:1-8.
5. Derevenskaya O, Unkovskaya E, Kosova M. Indices of zooplankton in assessing the ecological state of lake Ilinskoe (Russia). Turk Online J Des Art Commun 2017; 7:1787-94.

6. Derevenskaya OY. Zooplankton community of lake Lebyazh'e (Kazan, Russia) under changing conditions. Uch Zap Kazan Univ Seriya Estestven Nauki 2017; 159:108-21.

7. Özdemir MD, Ustaoğlu M. Distribution of rotifers of high mountain lakes in the eastern black sea range of Turkey. Turk J Zool 2017;41:674-85.

8. Winberg GG. Methodical recommendations for the collection and processing of materials for hydrobiological research of freshwater reservoirs. In: Zooplankton and its Products. London: Zoological Institute of the USSR Academy of Sciences-National Research Institute of Lake and River Fisheries; 1982. p. 33.

9. Shannon CE, Weaver W. The Mathematical Theory of Communication. Urbana: University Illinois Press; 1949. p. 117.

10. Sladeček V. System of water quality from biological point of view. Egetnisse Limnol 1973;7:218.

Source of Support: Nil. Conflict of Interest: None declared. 